\title{
LABDARÚGÓ AKADÉMIÁSOK SPORTON KÍVÜLI TEVÉKENYSÉGEI
}

\author{
BOGNÁR JÓZSEF ${ }^{a, \star}$ - KISS ZOLTÁN ${ }^{b, c}-$ DÉRI DIÁNA ${ }^{c}-$ CSÁKI ISTVÁN ${ }^{c}$ \\ ${ }^{a}$ Eszterházy Károly Katolikus Egyetem Sporttudományi Intézet \\ ${ }^{\text {b} P u s k a ́ s ~ F e r e n c ~ L a b d a r u ́ g o ́ ~ A k a d e ́ m i a ~}$ \\ ${ }^{\mathrm{c}}$ Eszterházy Károly Katolikus Egyetem Neveléstudományi Doktori Iskola \\ Beérkezett: 2021. február 10., elfogadva: 2021. november 29.
}

\begin{abstract}
Vizsgálatunk célja, hogy összehasonlítsa az edzők, a sportolók és a szülők nézeteit és tapasztalatait arra vonatkozóan, hogy az edzők mennyire foglalkoznak a fiatal játékosok sporttevékenységen kívüli életvitelével. A vizsgálatot egy magyar kiemelt labdarúgó akadémián végeztük el, a zárt végű kérdőívet edzők $(n=18)$, utánpótlás korú labdarúgók $(n=87)$ és szüleik $(n=80)$ töltötték ki. Az egészséges életmód, az edzők nevelői attitűdje és az iskolai oktatáshoz kapcsolódó terület tekintetében bizonyos hasonlóság mellett különbség is mutatkozott az alminták között, hasonlóan, a különböző korosztályt képviselő labdarúgók között is. Fontos az edzők azon ismerete és tevékenysége, mely a játékosok sportoláson kívüli életére vonatkozik, mivel ez fejlesztheti az együttmüködést és kommunikációt a szülőkkel és a játékosokkal is, így jótékony hatású a közösségre és a teljesítményre is.
\end{abstract}

Kulcsszavak: tehetséggondozás, labdarúgás, akadémia, edzők pedagógiai tevékenysége

The aim of our study is to compare the views and experiences of coaches, athletes and parents about the extent to which coaches deal with young players' non-sporting lifestyles. The study was carried out in a Hungarian elite soccer academy, closed-ended questions were answered by coaches $(n=18)$, young soccer players $(n=87)$ and their parents $(n=80)$. In addition to some similarities in terms of healthy living, educational attitudes of coaches, and the area related to school education, there were also differences between the subsamples, as well as between soccer players of different ages. The knowledge and activity of coaches regarding the non-sporting lives of players is important as it can improve collaboration and communication with parents and players as well, thus benefiting the community and performance as well.

Keywords: talent development, soccer, academy, pedagogical activities of coaches

\footnotetext{
* Levelező szerző: Bognár József, Eszterházy Károly Katolikus Egyetem, Sporttudományi Intézet, 3300 Eger, Leányka u.6.E-mail: bognar.jozsef@uni-eszterhazy.hu
} 


\section{Bevezetés}

$\mathrm{H}$ azánkban a sportakadémiák gondoskodnak a fiatal labdarúgó tehetségek felkészítéséről és versenyeztetéséről, egyúttal hathatós segítséget nyújtanak a tankötelezettség és az élsport összehangolásában is. A sportakadémiákban az edzők, a pedagógusok és a kollégiumi nevelők alkotta személyi környezet együttes hatásrendszere fontos tényező a szisztematikus és komplex fejlesztésben (Vincze et. al. 2011).

$\mathrm{A} z$ iskola és a kollégium, mint sporton kívüli tevékenységszférák, szerves elemként vannak jelen a fiatal labdarúgók fejlesztésében és életének szervezésében, valamint egyértelmü felelősséggel tartoznak a közösség, a szülők és a fiatalok felé is. Az iskolától és a kollégiumtól intézményi és társadalmi elvárás is, hogy a tanulókat az életre, illetve konkrétabban az érettségire, a felsőfokú tanulmányokra, a szakvizsgára és a munka világára készítse fel. Ebben kiemelt jelentőséget kapnak azok a személyi és tárgyi feltételek, melyek lehetővé teszik, hogy a labdarúgók a sportban, az iskolában és a tágabb közösségben is a képességüknek, érdekeiknek és igényeiknek megfelelően teljesíthessenek.

$\mathrm{A} z$ akadémiákról kikerülő labdarúgók felnőttként különböző közösségek (munkahely, család, futballcsapat) tagjai lesznek. Ezért nem mindegy a társadalom szempontjából, hogy itt milyen készségek elsajátítása és milyen képességek fejlesztése valósul meg. A $z$ edző, az iskola és a kollégium közös feladata, hogy aktív, egészséges, a társadalom különböző területein alkotni tudó, fizikai, értelmi, lelki és szociális képességeiknek megfelelően teljesítő, müvelt személyek hagyják el az akadémia kapuját (PFLA Kollégium Pedagógiai Program 2018).

\section{Elméleti háttér}

A sport olyan teljesítménycentrikus tevékenységnek számít, amely számottevő személyiség- és közösségfejlesztő hatással is rendelkezik. Ebben a tehetséggondozási folyamatban az általános és sportágspecifikus motorikus, a fittségi, a pszichés és a pedagógiai módszerek innovatív fejlesztése is jelentős szerepet játszik (Csáki et al. 2013b). A témát érintő szakirodalom a szakmai tudás, felelősség és elhivatottság mellett elsősorban az edzők felelősségének, pedagógiai felkészültségének és kommunikációs képességének jelentőségét emeli ki (Bognár-Kiss 2020). Vagyis a folyamatban kiemelt szerepe van az edzők célirányos tervezőmunkájának és tudatosságának. Egyértelmü emellett az is, hogy az edző-sportoló kapcsolat elsődleges befolyásoló tényezőnek számít az ifjú sportolók tehetségének hosszú távú kibontakoztatásában és sikerességében, vagyis a beválásban (Trzaskoma-Bicsérdy et al. 2007). Az edző személyisége és az edző-sportoló kapcsolat közvetlenül meghatározza a sportbeli teljesítményt és egyúttal a fiatalok személyiségfejlődését és szocializációs folyamatait is (Gombocz 2004).

$\mathrm{Az}$ akadémiák személyi környezetére, a benne rejlö munka- és emberi kapcsolatok kialakítására és fejlesztésére komoly hatással vannak az edzők és a sportvezetők, mivel jelentősen befolyásolják a fiatal játékosok intézményeikhez való kötődését és elköteleződését (Platts 2012). Ugyanakkor bizonyítást nyert, hogy a labdarúgó edzők nem szentelnek elég figyelmet játékosaik versenysporton kívüli tevékenységeire, egyúttal az értelmi képességeikre és intelligenciájukra sem (Varga 2017). Emellett az edzők nem fogalmaznak meg 
egyértelműen pozitív véleményt a sportolók feléjük megnyilvánuló érzelmi kötődéseiről és a sportolókkal való kapcsolatrendszerükről sem (Varga-Kovács-Gombocz 2018). A játékosok viszont szakmai, személyi és szociális szempontból is elégedettek az adott labdarúgó akadémia szolgáltatásaival (Rábai 2019) és a fejlődésük tekintetében kiemelik az edző motiváló szerepét és személyiségét (Csáki et al. 2013b). A labdarúgók szerint az edzők igyekeznek empatikusak és segítőkészek lenni a szakmai munka mellett a mindennapos tevékenységek során is (Rábai 2018).

A nevelőhatás eltérő módon és eredménnyel jelentkezhet az oktatási intézményekben és a versenysport rendszerében. A nem megfelelő hatásrendszer a versenysportban a személyiséget negatív irányba is befolyásolhatja (Gombocz 2004), azonban az optimális személyi és tárgyi környezetben a sport konstruktív hatásrendszere erőteljesebb lehet, mint az iskoláé (Rókusfalvi 1981). Hozzátéve, hogy az edzők akkor tudnak hatékony és hatásos nevelőtevékenységet folytatni, ha a szülők partnerek a folyamatban (Bognár et al. 2006). Egyértelmű, hogy a szülők jelentős szerepet játszanak a gyermek sportágának kiválasztásában, a fizikai aktivitás megszerettetésében, a fiatalok sportolási szokásainak kialakításában, valamint ezen keresztül a sportban megmutatkozó teljesítőképességben és egyúttal sikerességben is (Csáki et al. 2013a). Ebben a tekintetben fontos a szülök sportági elkötelezettsége (Révész et al. 2005), és az, hogy a szülő miként viszonyul gyermeke edzéstevékenységéhez, versenyeihez, valamint az edző oktató-nevelő munkájához (Mizsér 2018).

Egyértelmü, hogy a tehetség optimális kibontakoztatása érdekében szükség van az iskola és a család szoros együttmüködésére (Balogh 2014). A szülök mellett azonban a pedagógusoknak is kulcsfontosságú szerepük van az utánpótlás-nevelés folyamatában, melynek során kiemelt feladatként jelenik meg a tanulók személyiségének kibontakoztatása, az értelmi, érzelmi és szociális képességük fejlesztése (Duró 2004; Orosz 2010). Amennyiben az iskolai légkör nemcsak az értelmi képességek fejlesztésére helyez hangsúlyt, hanem a sporttevékenység fontosságát is közvetíti, úgy az egészségtudatos életmódra nevelést hosszú távon siker koronázhatja (Bábosik 2016).

\section{A kutatás célja}

Kutatásunk fő célja egy kiemelt labdarúgó akadémián a játékosok, szülők és edzők tapasztalatai alapján bemutatni azt, hogy az edzők mennyire foglalkoznak a játékosok sporton kívüli tevékenységeivel és élethelyzeteivel. Az edző sportszakmán túli tevékenységének alábbi három területére koncentráltunk:

1. egészséges életmód (káros szenvedélyek elkerülése, sportolói táplálkozás, időjárásnak megfelelö öltözet),

2. edzők nevelői attitűdje (a sportolók magánélete, napirendje, magatartása, viselkedése, a feladatok kötelességtudó elvégzése és a szülőkkel való kapcsolat),

3. iskolai oktatás (együttmüködés az iskola tanáraival, tanulmányi eredmény).

A fó cél mellett a labdarúgó korosztályok közötti különbségeket is célunk volt kimutatni. 


\section{A kutatás módszertana}

\section{Módszer és mintaválasztás}

A vizsgálatot Magyarország egyik kiemelt akadémiáján végeztük el. A kutatás folyamán minden edzőt, utánpótláskorú labdarúgót és szüleiket kértük meg a válaszadásra. Az edzőknél és a játékosoknál a kitöltési arány megközelítőleg 100\%-s, míg a szülőknél 91,9\%-os volt. A fiatal sportolók négy különböző korosztályt (U15, U16, U17 és U19) képviseltek, akik valamennyien az intézmény kollégiumában laknak és a középiskolájában tanulnak (1. táblázat).

1. táblázat: A vizsgálatban részt vevő személyek számának csoportonkénti megoszlása (fó)

\begin{tabular}{ccccccc}
\hline Edzők & Szülők & U15 & U16 & U17 & U19 & Összesen \\
\hline 18 & 80 & 18 & 22 & 20 & 27 & 185 \\
\hline
\end{tabular}

Forrás: Saját adatfelvétel

\section{Adatfelvétel}

A vizsgálathoz kérdőíves módszert alkalmaztunk. A kérdések segítségével azt tártuk fel, hogy az edzők, a sportolók és a szülők nézete és tapasztalata szerint az edzők menynyire foglalkoznak a fiatal játékosok sporton kívüli életével.

A kérdőív tíz zárt kérdést tartalmazott, a játékosoknak, edzőknek és szülőknek 1-től 4-ig terjedő skálán kellett meghatározni, hogy mennyire értenek egyet az adott állítással: az 1-es érték jelentette a kérdéssel vagy meghatározással való teljes egyet nem értést, a 4-es érték pedig az állítással való teljes egyetértést.

$\mathrm{A} z$ adatfelvétel a játékosok és az edzők esetében hétköznap, egy délutáni edzés előtt történt 2019 márciusában. Az adott korosztályos csapat edzője mellett a szerzők közül egy mindig jelen volt, hogy elmagyarázza a célokat és a tesztek lényegét, illetve, hogy tudjon az esetlegesen felmerülő kérdésekre válaszolni. A szülők saját otthonukban töltötték ki a kérdőívet, amelyeket visszajuttattak a felmérést végző személyekhez.

$\mathrm{A} z$ akadémiát irányító testület jóváhagyta a kutatást. Minden résztvevő aláírta az etikai nyilatkozatot, míg a 18 év alatti gyerekek szülei írásban járultak hozzá gyermekük vizsgálatban való részvételéhez.

\section{Adatelemzés}

Az adatok elemzéséhez az SPSS 25.0 statisztikai programot alkalmaztuk. A minta jellemzéséhez leíró statisztikát, az alminták és a korosztályok különbözőségeinek bemutatására varianciaanalízist (Post Hoc) és diszkriminanciaanalízist (stepwise módszer) alkalmaztunk. Szignifikanciaszintnek az 5\%-os hibahatárt vettük alapul. 


\section{Eredmények}

$\mathrm{Az}$ egészséges életmódhoz kapcsolódó (1-3.) állítások mind aránylag magas értékekkel jellemezhetőek (2. táblázat). Az edzők, a labdarúgók és a szülők is leginkább azt hangsúlyozzák, hogy az edző odafigyel a sportolók időjárásnak megfelelő öltözetére $(M=$ 3,21 \pm 071$)$. Az edzők szignifikánsan magasabb értékekkel jellemezték ez irányú saját tevékenységüket, mint a sportolók és a szülők $(F=3,463, p=0,033)$.

Az edzők nevelői attitűdjét (4-8. itemek) vizsgálva elmondható, hogy az edzők, a labdarúgók és a szülők is kifejezetten magas pontszámmal értékelték a sportolók kötelességtudó feladatvégzését $(M=3,50 \pm 0,67)$ és a magatartással és viselkedéssel való foglalkozást $(M=3,34 \pm 0,69)$. Az edzők legkevésbé a játékosok magánéletével foglalkoznak $(M=2,61 \pm 0,86)$. A nevelői attitűd tekintetében a három csoport között statisztikailag kimutatható különbséget egy esetben találtunk. Az edzők gondolják leginkább úgy, hogy foglalkoznak a játékosok magatartásával és viselkedésével $(F=3,081$, $p=0,048)$.

$\mathrm{Az}$ iskolai oktatáshoz köthető (9-10.) állításokat tekintve elmondható, hogy az edzők jellemzően együttműködnek a pedagógusokkal $(M=3,01 \pm 0,81)$ és aránylag fontosnak tartják a játékosok tanulását $(2,89 \pm 0,81)$. Ezekben a kérdésekben nem volt lényeges különbség a három alminta válaszai között.

2. táblázat: Az egészséges életmód (1-3), az edzők nevelői attitüdje (4-8), az iskolai oktatás (9-10) átlagai, szórásai és varianciaanalízise a három alminta alapján

\begin{tabular}{|c|c|c|c|c|c|}
\hline \multirow{2}{*}{ Állítások } & Edzöa & Szülőb & Sportolóc $^{c}$ & Összesen & \multirow{2}{*}{$F / p$} \\
\hline & $M \pm S D$ & $M \pm S D$ & $M \pm S D$ & $M \pm S D$ & \\
\hline $\begin{array}{l}\text { Figyel a káros } \\
\text { 1. szenvedélyek } \\
\text { elkerülésére }\end{array}$ & $3,28 \pm 0,82$ & $3,14 \pm 0,91$ & $2,91 \pm 0,85$ & $3,04 \pm 0,88$ & $2,13 / 0,121$ \\
\hline $\begin{array}{l}\text { Figyel az egészséges } \\
\text { sporttáplálkozásra }\end{array}$ & $3,33 \pm 0,59$ & $3,05 \pm 0,85$ & $2,93 \pm 0,86$ & $3,02 \pm 0,84$ & $1,80 / 0,167$ \\
\hline $\begin{array}{l}\text { Figyel az időjárásnak } \\
\text { megfelelö öltözetre* }\end{array}$ & $3,61 \pm 0,5^{b c}$ & $3,13 \pm 0,76^{a}$ & $3,21 \pm 0,68^{a}$ & $3,21 \pm 0,71$ & $3,46 / 0,033$ \\
\hline $\begin{array}{l}\text { Figyel a napirend } \\
\text { betartására }\end{array}$ & $3,39 \pm 0,5$ & $3,0 \pm 0,9$ & $2,9 \pm 0,77$ & $2,99 \pm 0,82$ & $2,74 / 0,067$ \\
\hline $\begin{array}{l}\text { 5. Foglalkozik a } \\
\text { magánéletével }\end{array}$ & $2,78 \pm 0,73$ & $2,58 \pm 0,96$ & $2,6 \pm 0,79$ & $2,61 \pm 0,86$ & $0,40 / 0,667$ \\
\hline $\begin{array}{l}\text { 6. Együttmüködik a } \\
\text { szülőkkel }\end{array}$ & $3,17 \pm 0,78$ & $2,94 \pm 0,93$ & $2,77 \pm 0,94$ & $2,88 \pm 0,93$ & $1,62 / 0,200$ \\
\hline $\begin{array}{l}\text { Foglalkozik a } \\
\text { 7. } \begin{array}{l}\text { magatartással, } \\
\text { viselkedéssel }\end{array}\end{array}$ & $3,72 \pm 0,46^{b c}$ & $3,3 \pm 0,75^{a}$ & $3,3 \pm 0,65^{a}$ & $3,34 \pm 0,69$ & $3,08 / 0,048$ \\
\hline $\begin{array}{l}\text { Fontos a feladatok } \\
\text { 8. elvégzése } \\
\text { kötelességtudóan }\end{array}$ & $3,67 \pm 0,48$ & $3,44 \pm 0,79$ & $3,53 \pm 0,58$ & $3,50 \pm 0,67$ & $0,96 / 0,383$ \\
\hline
\end{tabular}


2. táblázat: (folyt.)

\begin{tabular}{|c|c|c|c|c|c|}
\hline \multirow{2}{*}{ Állítások } & Edző & Szülöb & Sportolóc $^{c}$ & Összesen & \multirow{2}{*}{$F / p$} \\
\hline & $M \pm S D$ & $M \pm S D$ & $M \pm S D$ & $M \pm S D$ & \\
\hline $\begin{array}{l}\text { Együttmúködik az } \\
\text { iskola tanáraival }\end{array}$ & $3,17 \pm 0,51$ & $2,95 \pm 0,89$ & $3,02 \pm 0,78$ & $3,01 \pm 0,81$ & $0,55 / 0,573$ \\
\hline 10. $\begin{array}{l}\text { Fontos a } \\
\text { képességnek } \\
\text { megfelelö tanulás }\end{array}$ & $3,06 \pm 0,8$ & $2,95 \pm 0,87$ & $2,79 \pm 0,76$ & $2,89 \pm 0,81$ & $1,20 / 0,304$ \\
\hline
\end{tabular}

Megjegyzés: Az egyes állításokkal való egyetértés összpontszámának terjedelme: 1-4. A * és az adott változóhoz illő felső indexek az átlagok páronkénti összehasonlításának eredményeként kapott szignifikáns különbségeket jelzik az alminták között $(p<0,05)$.

Forrás: Saját adatfelvétel

Diszkriminanciaanalízis segítségével a három alminta között két változó megkülönböztető szerepe mutatható ki (3. táblázat), melyek az egészséges életmódhoz köthetőek: „figyel az időjárásnak megfelelő öltözetre” és „figyel a káros szenvedélyek elkerülésére".

3. táblázat: Az egészséges életmód, az edzők nevelői attitűdje és az iskolai oktatás itemeinek diszkriminanciaelemzése a három alminta vonatkozásában

\begin{tabular}{|c|c|c|c|c|c|c|c|c|c|}
\hline \multirow{3}{*}{ 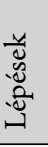 } & \multirow{3}{*}{ Bevont változók } & \multicolumn{8}{|c|}{ Wilks' Lambda } \\
\hline & & \multirow{2}{*}{ Stat. } & \multirow{2}{*}{$d f 1$} & \multirow{2}{*}{$d f 2$} & \multirow{2}{*}{$d f 3$} & \multicolumn{4}{|c|}{ Exact $F$} \\
\hline & & & & & & Stat. & $d f 1$ & $d f 2$ & Sig. \\
\hline 1. & $\begin{array}{l}\text { Figyel az időjárásnak } \\
\text { megfelelő öltözetre }\end{array}$ & 0,963 & 1 & 2 & 180 & 3,502 & 2 & 180 & 0,032 \\
\hline 2. & $\begin{array}{l}\text { Figyel a káros } \\
\text { szenvedélyek elkerülésére }\end{array}$ & 0,942 & 2 & 2 & 180 & 2,697 & 4 & 358 & 0,031 \\
\hline
\end{tabular}

Forrás: Saját adatfelvétel

Az egészséges életmódhoz, az edzők nevelői attitűdjéhez, az iskolai oktatáshoz kapcsolódó válaszokat összehasonlítva a korosztályonkénti mintában 3 kérdésben találtunk szignifikáns különbséget (4. táblázat). A 15 és 17 éves labdarúgók véleménye szerint edzőik komoly figyelmet szentelnek az egészséges sporttáplálkozásra, ellentétben a 16 és 19 éves korosztályokkal $(F=6,293, p=0,001)$. A legfiatalabb korcsoporthoz tartozó fiúk szignifikánsan többen jelezték, hogy az ő edzőik müködnek a leginkább együtt a szüleikkel, mint az idősebb játékosok $(F=3,825, p=0,013)$. Az U16-os csapat tagjai a többi korosztályhoz viszonyítva jelentősen kisebb mértékben tapasztalják, hogy az edzők fontosnak tartják a képességnek megfelelö tanulási eredményeket $(F=4,023$; $p=0,01)$.

Diszkriminanciaanalízis alapján öt változó mutatja a korosztályok közötti érdemi megkülönböztető tényezőket (5. táblázat), melyek közül a leginkább befolyásoló tényező az egészséges életmódhoz köthető: „figyel az egészséges sporttáplálkozásra”. A többi item az edzők nevelői attitűdje és az iskolai oktatás alskáláihoz tartozik, melyek hatása 
BOGNÁR J. - KISS Z. - DÉRI D. - CSÁKI I.: LABDARÚGÓ AKADÉMIÁSOK...

4, táblázat: Az egészséges életmód, az edzők nevelői attitűdje és az iskolai oktatás itemeinek átlagai és szórásai korosztályok szerint

\begin{tabular}{|c|c|c|c|c|c|c|}
\hline \multirow{2}{*}{ Állítások } & $\mathrm{U} 15^{\mathrm{a}}$ & $\mathrm{U} 16^{\mathrm{b}}$ & $\mathrm{U} 17^{\mathrm{c}}$ & U19d & Összesen & \multirow{2}{*}{$F / p$} \\
\hline & $M \pm S D$ & $M \pm S D$ & $M \pm S D$ & $M \pm S D$ & $M \pm S D$ & \\
\hline
\end{tabular}

Figyel a káros

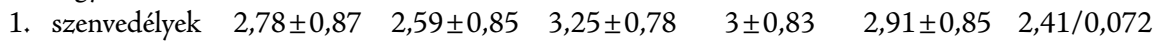
elkerülésére

Figyel az

2. $\begin{aligned} & \text { egészséges } \\ & \text { sporttáplál- }\end{aligned} \quad 3,44 \pm 0,7^{\text {bd }} \quad 2,64 \pm 0,9^{\text {ac }} \quad 3,25 \pm 0,85^{\text {bd }} 2,59 \pm 0,69^{\text {ac }} \quad 2,93 \pm 0,86 \quad 6,29 / 0,001$ kozásra* $^{*}$

Figyel az

3. $\begin{aligned} & \text { időjárásnak } \\ & \text { megfelelö }\end{aligned} \quad 3,28 \pm 0,66 \quad 3,18 \pm 0,66 \quad 3,15 \pm 0,74 \quad 3,22 \pm 0,69 \quad 3,21 \pm 0,68 \quad 0,12 / 0,948$ öltözetre

Figyel a

4. napirend $\quad 2,83 \pm 0,7 \quad 2,77 \pm 0,86 \quad 3,05 \pm 0,94 \quad 2,93 \pm 0,61 \quad 2,9 \pm 0,77 \quad 0,48 / 0,691$ betartására

Foglalkozik

5. a magánéle- $\quad 2,56 \pm 0,61 \quad 2,45 \pm 0,85 \quad 2,6 \pm 0,82 \quad 2,74 \pm 0,85 \quad 2,6 \pm 0,79 \quad 0,53 / 0,662$ tével

Együttmü-

6. ködik a $\quad 3,39 \pm 0,69^{\text {bcd }} 2,68 \pm 0,94^{a} \quad 2,45 \pm 0,82^{\text {a }} \quad 2,67 \pm 1,03^{\text {a }} \quad 2,77 \pm 0,94 \quad 3,82 / 0,013$ szülökkel ${ }^{*}$

Foglalkozik a

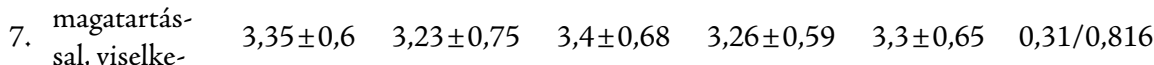
déssel

Fontos a

feladatok

8. elvégzése $\quad 3,56 \pm 0,51 \quad 3,55 \pm 0,59 \quad 3,7 \pm 0,47 \quad 3,37 \pm 0,68 \quad 3,53 \pm 0,58 \quad 1,25 / 0,297$ kötelességtudóan

Együtt-

9. müködik $\quad 3,17 \pm 0,7 \quad 2,68 \pm 0,89 \quad 3,15 \pm 0,87 \quad 3,12 \pm 0,58 \quad 3,02 \pm 0,78 \quad 1,96 / 0,126$ tanáraival

Fontos a

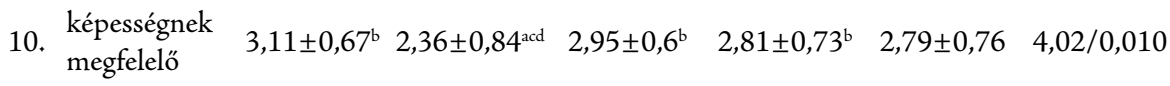
tanulás*

Megjegyzés: Az egyes állításokkal való egyetértés összpontszámának terjedelme: 1-4. A * és az adott változóhoz illő felső indexek az átlagok páronkénti összehasonlításának eredményeként kapott szignifikáns különbségeket jelzik az alminták között $(p<0,05)$.

Forrás: Saját adatfelvétel 
5. táblázat: Az egészséges életmód, az edzők nevelői attitüdje és az iskolai oktatás itemeinek diszkriminanciaelemzése a korosztályok vonatkozásában

\begin{tabular}{|c|c|c|c|c|c|c|c|c|c|}
\hline \multirow{3}{*}{ 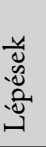 } & \multirow{3}{*}{ Bevont változók } & \multicolumn{8}{|c|}{ Wilks' Lambda } \\
\hline & & \multirow{2}{*}{ Stat. } & \multirow{2}{*}{$d f 1$} & \multirow{2}{*}{$d f 2$} & \multirow{2}{*}{$d f 3$} & \multicolumn{4}{|c|}{ Exact $F$} \\
\hline & & & & & & Stat. & $d f 1$ & $d f 2$ & Sig. \\
\hline 1. & $\begin{array}{l}\text { Figyel az egészséges sport- } \\
\text { táplálkozásra }\end{array}$ & 0,830 & 1 & 3 & 81 & 5,528 & 3 & 81 & 0,002 \\
\hline 2. & Együttmüködik a szülőkkel & 0,748 & 2 & 3 & 81 & 4,172 & 6 & 160 & 0,001 \\
\hline 3. & $\begin{array}{l}\text { Együttmüködik az iskola } \\
\text { tanáraival }\end{array}$ & 0,661 & 3 & 3 & 81 & 3,961 & 9 & 192,416 & 0,000 \\
\hline 4. & Figyel a napirend betartására & 0,598 & 4 & 3 & 81 & 3,693 & 12 & 206,66 & 0,000 \\
\hline 5. & $\begin{array}{l}\text { Fontos a képességnek meg- } \\
\text { felelő tanulás }\end{array}$ & 0,554 & 5 & 3 & 81 & 3,391 & 15 & 212,964 & 0,000 \\
\hline
\end{tabular}

Forrás: Saját adatfelvétel

csökkenő sorrendben az „együttmüködik a szülőkkel”, az „együttmüködik az iskola tanáraival”, a „figyel a napirend betartására”, és a „fontos a képességnek megfelelő tanulás”.

\section{Megbeszélés, konklúzió}

A kutatásban Magyarország egyik kiemelt labdarúgó akadémiáján dolgozó edzők sportszakmán kívüli pedagógiai tevékenységeit vizsgáltuk a játékosok, a szülők és az edzők véleményeire alapozva. Eredményeink alapján kijelenthető, hogy az edzők, a fiatal labdarúgók és a szülők véleménye eltérő az edzők ilyen irányú tevékenységével kapcsolatban. Ennek egyik lehetséges oka a három fél kommunikációjának hiányossága, illetve az edzők felé irányuló eredménykényszer szerepe. Az utánpótlásedzőknek szükséges megfelelő információval és átfogó képpel rendelkezniük a szülők gyermekeik tehetséggondozására és iskoláztatásra vonatkozó elképzeléseiről és sporton kívüli tevékenységeikről, amelyek mind hozzájárulhatnak az edzői munka komplex jellegének és eredményességének megerősítéséhez.

A játékosok, az edzők és a szülők is kiemelték, hogy az edzők számára nagy jelentőséggel bír a sportolók időjárásnak megfelelö öltözete, kötelességtudó feladatvégzése, valamint közel azonos nézetet vallanak arra a kérdésre vonatkozóan, hogy az edzők legkevésbé a játékosok magánéletével foglalkoznak. Az edzők azonban hangsúlyosabbnak érzik, hogy kiemelt figyelmet fordítanak az ifjú sportolók időjárásnak megfelelő öltözetére és a játékosok magatartására, viselkedésére, mint a játékosok és szüleik.

$\mathrm{A} z$ eredmények alapján elmondható, hogy a különböző korosztályt képviselő fiatal labdarúgók több kérdésben is eltérően ítélik meg edzőik szakmán túli feladatainak az elvégzését. Kijelenthető, hogy a labdarúgáshoz közvetlenül kapcsolódó tevékenységi területen túl is számítanak az edzőik feléjük irányuló érdeklődéseire, segítő, gondoskodó attitűdjeire. Elvárják edzőiktől a segítségnyújtást az élet egyéb szféráiban is, ezzel hozzájárulva ahhoz, hogy a fiatal tehetségek ne csak a labdarúgás terén, hanem az iskola kapuin belül is képességeiknek megfelelő tudásuk legjavát adhassák. 
Az egészséges életmód terén az U16-os és az U19-es csapat tagjai érzik elsősorban azt, hogy több odafigyelést igényelnének edzőiktől az egészséges sporttáplálkozást illetően. Ez azért lehet ilyen mértékü, mert a vizsgált akadémián fóállású dietetikus foglalkozik a játékosok egyéni étrendjének kialakításával, illetve a szakember egyéni konzultációkat is tart a sportolók számára. Az edzők nevelői attitüdjéhez kapcsolódó kérdések közül a legfiatalabbak (U15) értékelték a legmagasabbra az edzőik szüleikkel való együttműködését. Erre az együttműködésre szükség lenne az idősebb korosztályok esetében is, enélkül a játékosok optimális fejlődése nem valósulhat meg. Az iskolai oktatást érintő kérdésekre vonatkozóan az U16-os csapat labdarúgói érzik leginkább, hogy a korcsoportjuk edzői stábját alkotó szakemberek nem tekintenek jelentős tényezőként a képességnek megfelelő tanulmányi eredményekre. Minden bizonnyal ennek személyi okai vannak, mely bizonyítására további kutatások szükségesek.

Ismert, hogy a sport intézményrendszerének, a családnak és az iskolának együttesen kell a fiatalok személyiségének optimális fejlődését biztosítani (Biróné 2004). A nevelésközpontú oktatás fókuszában a személyiség formálása foglal helyet, amely ellenőrzött formában, szervezett keretek között és megfelelő együttműködés során válhat valóra (Makszin 2012). Mindezek alapján elmondható, hogy érdemes a sporton kívüli pedagógiai tevékenységekre vonatkozó ismereteinket bővíteni. Ennek egyik része az akadémián sportoló fiatalok egyéb tevékenységeire irányulhat, míg érdekes lehet más hazai és határon túli intézményt vagy klubot is bevonni hasonló kutatásokba. A további tudományos alapokon nyugvó adatok újabb támpontot nyújthatnak az edzők számára, hogy milyen módszerekkel, eszközökkel segíthetik a sportolókat abban, hogy a sportolás során formálódó erényeik egyéb tevékenységszférákban is megnyilvánulhassanak, vagyis a sporton kívüli életükre is hatással legyenek.

\section{IRODALOM}

BÁвоsıк Z. (2016) A mozgás szerepe a szociális életképesség megalapozásában. In: HAMAR P. (ed.) A mozgás, mint személyiségfejlesztő tényezö. Budapest, Eötvös József Könyvkiadó. pp. 65-76.

BALOgh L. (2014) A pedagógus és a szülő együttműködésének gyakorlati aspektusai. In: Balogh L., Bolló Cs., Dávid I., Tóth L. \& Tóth T. (eds) A pedagógusok, szülök együttmüködése és a kollégiumok szerepe a tehetségfejlesztésben. Budapest, Magyar Tehetségsegítő Szervezetek Szövetsége. pp. 134-193.

Biróné Nagy E. (2004, ed.) Sportpedagógia. Kézikönyv a testnevelés és sport pedagógiai kérdéseinek tanulmányozásához. Budapest-Pécs, Dialóg Campus Kiadó.

Bognár J. \& Kiss Z. (2020) Nevelés a labdarúgásban. In: Csáki I. \& TAKÁcs M. (eds) Labdarúgás és tudomány. Felcsút-Budapest, Puskás Akadémia-Magyar Testnevelési Egyetem. pp. 319-366.

Bognár J., Trzaskoma-Bicsérdy G., Révész L. \& Géczi G. (2006) A szülők szerepe a sporttehetség-gondozásban. Kalokagatbia, Vol. 44. No. 1-2. pp. 86-95.

Csáki I., Bognár J., Révész L. \& Géczi G. (2013a) Elméletek és gyakorlatok a tehetséges labdarúgó kiválasztásához és beválásához. Magyar Sporttudományi Szemle, Vol. 14. No. 53. pp. 12-18.

Csáki I., Bognár J., Trzaskoma-Bicsérdy G., Zalai D., Mór O., Révész L. \& Géczi G. (2013b) A sportágválasztás, a tehetséggondozás és az edző-sportoló kapcsolat vizs- 
gálata elit utánpótláskorú labdarúgók körében. Magyar Sporttudományi Szemle, Vol. 14. No. 55. pp. 9-16.

Duró Zs. (2004) Tehetséges gyerekekröl mindenkinek. Budapest, Human Club Egyesület.

Gомвосz J. (2004) A testnevelő tanár és az edző pedagógiai szerepe. In: Biróné NaGy E. (ed.) Sportpedagógia. Kézikönyv a testnevelés és sport pedagógiai kérdéseinek tanulmányozásához. Budapest-Pécs, Dialóg Campus Kiadó. pp. 147-171.

Makszin I. (2012) A testnevelés elmélete és módszertana. Budapest-Pécs, Dialóg Campus Kiadó.

Mizsér A. (2018) Sportháromság. Budapest, Mediabook Kiadó.

Orosz R. (2010) A személyiségfejlesztés szerepe a tehetséggondozásban. In: INÁNTsY-PAP J., Orosz R., Péк Gy. \& Nagy T. (eds) Tehetség és személyiségfejlesztés. Budapest, Magyar Tehetségsegítő Szervezetek Szövetsége. pp. 49-70.

PFLA (2018) Puskás Ferenc Labdarúgó Akadémia Kollégium Pedagógia Programja. https:// www.pfla.hu/downloads/dokumentumok/Puskas_Ped_progr_2018.pdf [Letöltve: 2021. 02.01.]

Platts, C. (2012) Education and Welfare in Professional Football Academies and Centres of Excellence: A Sociological Study. University of Chester PhD thesis. https://chesterrep. openrepository.com/cdr/bitstream/10034/253657/35/chris+platts.pd [Letöltve: 2021. 02. 09.]

RÁваг D. (2018) Lila-fehér mezben - egy fővárosi és egy vidéki labdarúgó akadémia neveléstudományi megközelítésű vizsgálata, összehasonlítása. Iskolakultúra, Vol. 28. Nos 3-4. pp. 66-76.

RÁваг D. (2019) Labdarúgó akadémisták pedagógiai fókuszú, pilot jellegű kérdőíves vizsgálata. Magyar Sporttudományi Szemle, Vol. 20. No. 80. pp. 28-35.

Révész L., Géczi G., Bognár J. \& Tóth L. (2005) A sporttehetség megközelítési módjai. Magyar Edzö, Vol. 8. No. 4. pp. 5-8.

Rókusfalvi P. (1981) Sportpszichológia. Budapest, Sport.

Trzaskoma-Bicsérdy G., Bognár J., Révész L. \& Géczi G. (2007) The Coach-Athlete Relationship in Successful Hungarian Individual Sports. International Journal of Sport Science and Coaching, Vol. 2. No. 4. pp. 485-495.

VARGA D. (2017) Képben a gyermekkép: Labdarúgó edzők nézetei a mester és utánpótláskorú tanítványai kapcsolatáról. Magyar Sporttudományi Szemle, Vol. 18. No. 71. pp. 46-51.

VArga D., Kovács E. \& Gомвосz J. (2018) Edzők gyermekfelfogása a magyarországi labdarúgó akadémiákon. Magyar Sporttudományi Szemle, Vol. 19. No. 73. pp. 44-50.

Vincze G., Bognár J., CsÁki I. \& Géczi G. (2011) A labdarúgás szakmai elitje a sportág helyzetéről, fejlődési lehetőségeiről. Kalokagatbia, Vol. 49. Nos 2-4. pp. 277-288.

A cikk a Creative Commons Attribution 4.0 International License (https://creativecommons.org/licenses/ by/4.0/) feltételei szerint publikált Open Access közlemény, melynek szellemében a cikk bármilyen médiumban szabadon felhasználható, megosztható és újraközölhető, feltéve, hogy az eredeti szerző és a közlés helye, illetve a CC License linkje és az esetlegesen végrehajtott módosítások feltüntetésre kerülnek. (SID_1) 